\title{
The role of olfactory transport in the penetration of manganese oxide nanoparticles from blood into the brain
}

\author{
A.V. Romashchenko ${ }^{1,3}$ 凶, M.B. Sharapova ${ }^{1}$, K.N. Morozova $^{1}$, E.V. Kiseleva ${ }^{1}$, K.E. Kuper $^{2}$, D.V. Petrovskii ${ }^{1}$ \\ ${ }^{1}$ Institute of Cytology and Genetics, SB RAS, Novosibirsk, Russia \\ ${ }^{2}$ Budker Institute of Nuclear Physics, SB RAS, Novosibirsk, Russia \\ ${ }^{3}$ The Institute of Computational Technologies, SB RAS, Novosibirsk, Russia \\ 凶e-mail: yuter2006@yandex.ru
}

There is no doubt that various nanoparticles (NPs) can enter the brain from the nasal cavity. It is assumed that NPs can penetrate from blood into the central nervous system (CNS) only by breaking the blood-brain barrier (BBB). The accumulation of NPs in CNS can provoke many neurological diseases; therefore, the understanding of its mechanisms is of both academic and practical interest. Although hitting from the surface of the lungs into the bloodstream, NPs can accumulate in various mucous membranes, including the nasal mucosa. Thus, we cannot rule out the ability of NPs to be transported from the bloodstream to the brain through the olfactory uptake. To test this hypothesis, we used paramagnetic NPs of manganese oxide $\left(\mathrm{Mn}_{3} \mathrm{O}_{4}-\mathrm{NPs}\right)$, whose accumulation patterns in the mouse brain were recorded using T1-weighted magnetic resonance imaging. The effect of intranasal application of endocytosis and axonal transport inhibitors on the brain accumulation patterns of intranasally or intravenously injected $\mathrm{Mn}_{3} \mathrm{O}_{4}-\mathrm{NPs}$ was evaluated. A comparative analysis of the results showed that the transport of $\mathrm{Mn}_{3} \mathrm{O}_{4}-\mathrm{NPs}$ from the nasal cavity to the brain is more efficient than their local permeation through BBB into CNS from the bloodstream, for example with the accumulation of $\mathrm{Mn}_{3} \mathrm{O}_{4}-$ NPs in the dentate gyrus of the hippocampus, and through the capture and transport of NPs from the blood by olfactory epithelium cells. Also, experiments with the administration of chlorpromazine, a specific inhibitor of clathrin-dependent endocytosis, and methyl- $\beta$-cyclodextrin, inhibitor of the lipid rafts involved in the capture of substances by endothelium cells, showed differences in the mechanisms of NP uptake from the nasal cavity and from the bloodstream. In this study, we show a significant contribution of axonal transport to NP accumulation patterns in the brain, both from the nasal cavity and from the vascular bed. This explains the accumulation of different sorts of submicron particles (neurotropic viruses, insoluble xenobiotics, etc.), unable to pass BBB, in the brain. The results will add to the understanding of the pathogenesis of various neurodegenerative diseases and help studying the side effects of therapeutics administered intravenously.

Key words: nanoparticles; olfactory transport; magnetic resonance imaging; intravenous injection.

For citation: Romashchenko A.V., Sharapova M.B., Morozova K.N., Kiseleva E.V., Kuper K.E., Petrovskii D.V.The role of olfactory transport in the penetration of manganese oxide nanoparticles from blood into the brain. Vavilovskii Zhurnal Genetiki i Selektsii = Vavilov Journal of Genetics and Breeding. 2019;23(4):482-488. DOI 10.18699/VJ19.517

\section{Роль ольфакторного транспорта в проникновении наночастиц оксида марганца из кровеносного русла в мозг}

\author{
А.В. Ромащенко ${ }^{1,3}$ 囚, М.Б. Шарапова ${ }^{1}$, К.Н. Морозова ${ }^{1}$, Е.В. Киселева ${ }^{1}$, К.Э. Купер ${ }^{2}$, А.В. Петровский ${ }^{1}$ \\ 1 Федеральный исследовательский центр Институт цитологии и генетики Сибирского отделения Российской академии наук, \\ Новосибирск, Россия \\ ${ }^{2}$ Институт ядерной физики им. Г.И. Будкера Сибирского отделения Российской академии наук, Новосибирск, Россия \\ 3 Институт вычислительных технологий Сибирского отделения Российской академии наук, Новосибирск, Россия \\ 凶e-mail: yuter2006@yandex.ru
}

Возможность поступления из носовой полости в головной мозг наночастиц (НЧ) различной природы не вызывает сомнения. Как уже было показано ранее, накопление НЧ в центральной нервной системе (ЦНС) может спровоцировать целый ряд неврологических заболеваний, поэтому понимание механизмов данного процесса представляет интерес как с научной, так и с практической точек зрения. Предполагается, что из крови НЧ могут проникнуть в ЦНС, исключительно преодолев гематоэнцефалический барьер (ГЭБ). Попав с поверхности легких в кровеносное русло, НЧ могут накапливаться в различных слизистых оболочках, в том числе и в слизистой носовой полости. Таким образом, нельзя исключать возможность транспорта НЧ из кровотока в мозг за счет их захвата окончаниями обонятельных нейронов.

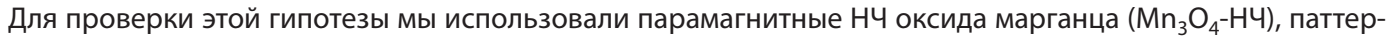
ны накопления которых в структурах мозга мыши регистрировали с помощью Т1-взвешенной магнитнорезонансной томографии. В настоящем исследовании была проведена оценка влияния интраназальной 


\begin{abstract}
аппликации ингибиторов эндоцитоза и аксонального транспорта на накопление $\mathrm{Mn}_{3} \mathrm{O}_{4}$-НЧ в структурах ЦНС при их введении в носовую полость или в кровоток. Сравнительный анализ полученных результатов показал, что перенос $\mathrm{Mn}_{3} \mathrm{O}_{4}-\mathrm{HЧ}$ из носовой полости в мозг эффективнее их проникновения в ЦНС из кровеносного русла, которое может осуществляться как за счет локального преодоления ГЭБ, например при накоплении $\mathrm{Mn}_{3} \mathrm{O}_{4}$-НЧ в зубчатой извилине гиппокампа, так и через захват и транспорт НЧ из крови клетками ольфакторного эпителия. При этом эксперименты с введением хлорпромазина, специфического ингибитора клатрин-зависимого эндоцитоза, и метил- $\beta$-циклодекстрина, вещества, разрушающего липидные рафты, участвующие в захвате веществ клетками эндотелия, продемонстрировали различия в механизмах захвата НЧ из носовой полости и кровеносного русла. В результате проведенного исследования нам удалось показать значимый вклад аксонального транспорта в поступление наночастиц в головной мозг как из носовой полости, так и из сосудистого русла. Это объясняет накопление в мозге субмикронных частиц различной природы (нейротропные вирусы, нерастворимые ксенобиотики и др.), которые не способны преодолевать ГЭБ. Полученные результаты будут полезны как для понимания патогенеза различных нейродегенеративных заболеваний, так и для исследования побочных эффектов терапевтических препаратов, вводимых внутривенно.

Ключевые слова: наночастицы; ольфакторный транспорт; магнитно-резонансная томография; внутривенное введение.
\end{abstract}

\section{Introduction}

People, like other mammalians, are constantly exposed to solid aerosols, which may include a great many of xenobiotics. Sedimentation of submicron and nanosized aerosols on the surface of the upper and lower respiratory tracts is followed by their penetration into blood and migration into internal organs, including the brain. Numerous experimental studies show that the accumulation of particulate matter in the brain of an animal leads to disruption of the dopaminergic and serotonergic systems of the brain and, as a consequence, to neurodegeneration (Tranfield, Walker, 2012). In addition, it is shown that people living than $50 \mathrm{~m}$ apart from motorways are at a dramatically higher risk of Alzheimer's disease. Analysis of the dependence of epidemiological situations on the concentration of solid aerosols and exhaust gases in the atmosphere shows that it is the concentration of solid particles in the air rather than the components of exhaust gases that influences the risk of neurodegenerative disorders (Chen et al., 2017).

Despite this, the respiratory and cardiovascular systems are considered the main targets for nanoaerosol toxicity (Donaldson et al., 2002; Chen et al., 2008; Brook et al., 2010; Kampfrath et al., 2011). Accordingly, most of the research is focused on the portal role of lungs in the penetration of nanoparticles into blood and their accumulation in internal organs, including the brain. At present, though, there is a significant body of experimental evidence for the key role of nasal epithelium in transporting nanoaerosols directly from the environment to the brain (Kreyling, 2016). For several viruses, the main route of penetration into the central nervous system of mammals is their transport from the nasal cavity to the brain. These include: herpes virus (HSV-1, HSV-2), (Kennedy, Chaudhuri, 2002), influenza A virus (Tanaka et al., 2003), bornaviruses (Sauder, Staeheli, 2003), rhabdoviruses, including rabies virus (Astic et al., 1993), parainfluenza (Mori et al., 2004), and prions (Zanusso et al., 2003). The basis of the olfactory transport of viruses and nanoparticles (Mistry et al., 2009) from the nasal cavity to the brain, is the uptake of the particles by the endings of the olfactory nerves, followed by movement inside the axons and passage through synaptic transmissions (Mori et al., 2005).
Since the nasal cavity is densely vascularized, NPs may enter the brain from the bloodstream. To assess the contribution of this process to the formation of observable spatiotemporal patterns of NP distribution in the mouse brain, we compared the accumulation of NPs in CNS after their intranasal and intravenous administrations. In this study, nanoparticles of manganese oxide $\left(\mathrm{Mn}_{3} \mathrm{O}_{4}-\mathrm{NP}\right)$ were used as an effective particulate paramagnetic agent detectable by magnetic resonance imaging (MRI). Assessment of $\mathrm{Mn}_{3} \mathrm{O}_{4}-\mathrm{NP}$ accumulation, based on the change in MRI signals in T1-weighted images of brain divisions of mice, was carried out $12 \mathrm{~h}$ after intranasal/ intravenous administration. According to the literature and our preliminary experiments, this time corresponds to the maximum accumulation of intranasally introduced nanoparticles in olfactory bulbs (OB) (Khlebtsov, Dykman, 2011). To identify the role of olfactory neurons in the transport of $\mathrm{Mn}_{3} \mathrm{O}_{4}$-NPs from the nasal cavity or bloodstream to the brain, the effect of preliminary nasal application of endocytosis and axonal transport inhibitors on the level of the MRI signal in CNS was investigated.

\section{Materials and methods}

Animals. Experiments were conducted with SPF Balb/c male mice (25-32 g, age 10-12 weeks, $n_{\text {total }}=64$ ). Manipulations were carried out at the Center for Genetic Resources of Laboratory Animals of the Institute of Cytology and Genetics, Siberian Branch of the Russian Academy of Sciences, Novosibirsk. Experimental mice were kept in unisexual family groups of 2-5 animals in individually ventilated (IVC) cells of the OptiMice system (Animal Care Systems) under controlled conditions, at $22-26^{\circ} \mathrm{C}$, relative humidity $30-60 \%$, and the light:dark schedule 14:10 with dawn at 01:00. Food (Ssniff, Germany) and deionized water enriched with "Severyanka" (St. Petersburg) mineral mixture were provided to animals ad libitum.

Nanoparticles. We used commercially available manganese oxide $\mathrm{Mn}_{3} \mathrm{O}_{4}$ nanoparticles $\left(\mathrm{Mn}_{3} \mathrm{O}_{4}\right.$-NPs, US3340, US-NANO, USA).

The crystal structure of the purchased manganese nanoparticles was determined by X-ray powder diffraction on the VEPP-3 accelerator complex with the following synchrotron 


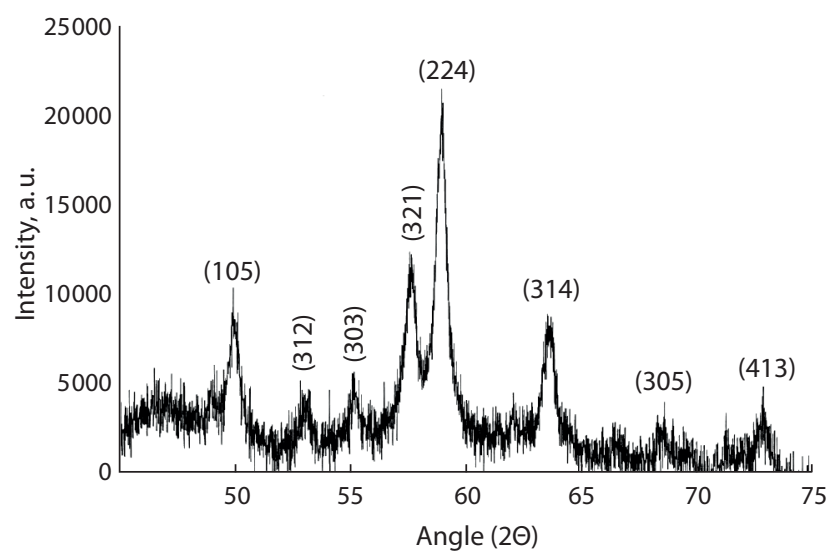

C

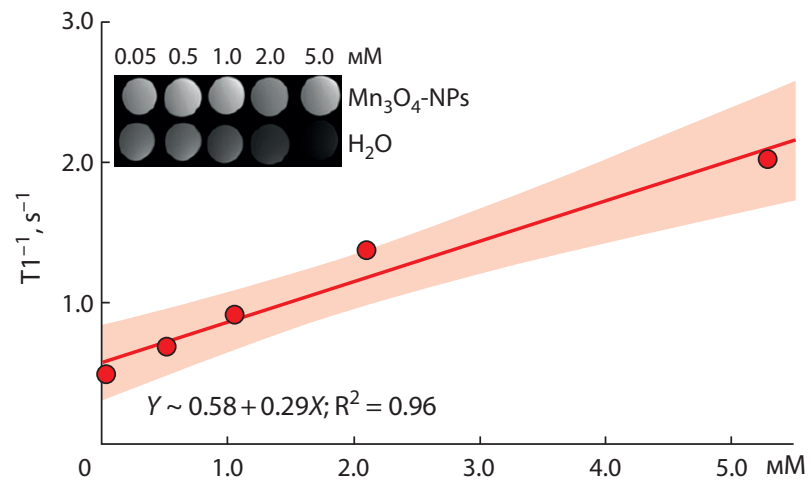

$b$

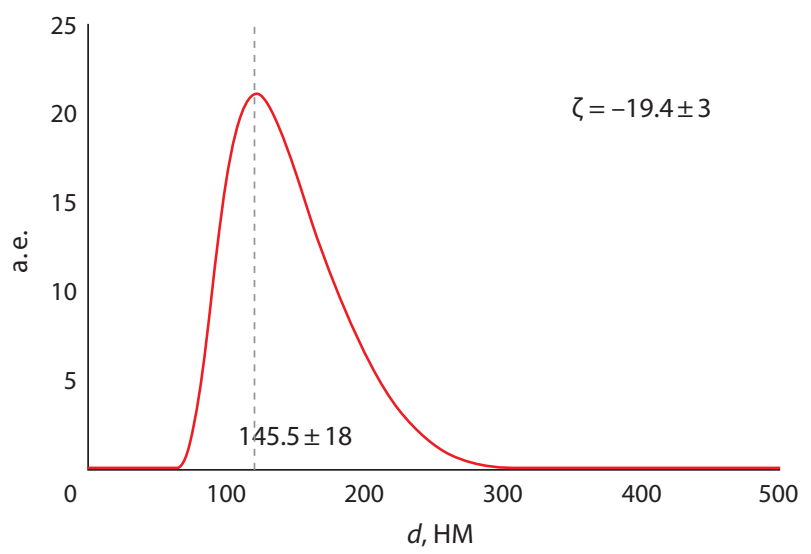

$d$

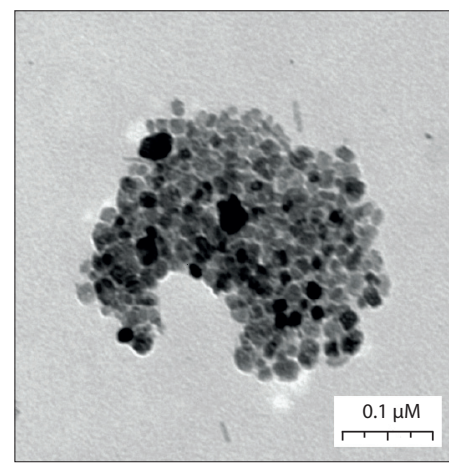

Fig. 1. Physicochemical characteristics of $\mathrm{Mn}_{3} \mathrm{O}_{4}-\mathrm{NPs}$.

$a$ - characterization of the crystalline phase in a sample of $\mathrm{Mn}_{3} \mathrm{O}_{4}$-NPs analyzed by powder X-ray diffraction; $b$ - the values of the hydrodynamic radius ( $d$ ) and zeta potential (ל) of $\mathrm{Mn}_{3} \mathrm{O}_{4}$-NPs assessed by dynamic light scattering; $c$ - dependence of the reciprocal of the relaxation time T1 on manganese concentration in the $\mathrm{Mn}_{3} \mathrm{O}_{4}$-NP samples; $d$ - high-resolution TEM image of the $\mathrm{Mn}_{3} \mathrm{O}_{4}$-NPs.

radiation parameters: monochromatic beam wavelength $\lambda=0.1516 \mathrm{~nm}$ and angular range $2 \theta$ from $45^{\circ}$ to $75^{\circ}$ (Fig. $\left.1, a\right)$. The hydrodynamic diameter of $\mathrm{Mn}_{3} \mathrm{O}_{4}$-NPs in a colloidal solution was determined by dynamic light scattering (angle $90^{\circ}$, temperature $22^{\circ} \mathrm{C}$ ) and the zeta potential using electrophoresis in a U-shaped cell as recommended by the manufacturer Zetasizer NanoZS (Malvern, England) (see Fig. 1, b). The morphology and shape of the nanoparticles were studied by transmission electron microscopy (TEM). The JEM 1400 microscope (JEOL, Japan) was equipped with a digital camera Veleta (SIS, Germany) (see Fig. 1, d).

As shown in our previous work, relaxation values ( $R 1$, $\mathrm{ms}^{-1}$, see Fig. 1, c) of $\mathrm{Mn}_{3} \mathrm{O}_{4}$-NPs correlate with manganese concentration in the samples (Romashchenko et al., 2017). In vivo experiments showed that the amplitude of the MRI signal in OB 12 hours after the intranasal application of $\mathrm{Mn}_{3} \mathrm{O}_{4}$-NPs was directly proportional to the manganese concentration in the tissue (Romashchenko et al., 2017). OB were taken for calibration, since the concentration of nanoparticles after the intranasal or inhalation administration is the highest in this region (Moshkin et al., 2014). Earlier, we demonstrated low solubility of $\mathrm{Mn}_{3} \mathrm{O}_{4}$-NPs at different $\mathrm{pH}(4-7)$, which entitled us to regard the observed changes in the MRI signal in mouse brain divisions after intranasal/intravenous administration of
$\mathrm{Mn}_{3} \mathrm{O}_{4}$-NPs as a result of accumulation of insoluble manganese rather than $\mathrm{Mn}^{2+}$ in the nervous tissue (Romashchenko et al., 2017) and use the level of the T1-weighted MRI signal to assess NP accumulation in the tissue.

Experimental design. Animals were injected with $10 \mu \mathrm{L}$ of a colloidal solution of particles $(5.5 \mathrm{mg} / \mathrm{mL})$ in one nostril or $100 \mu \mathrm{L}$ of $\mathrm{Mn}_{3} \mathrm{O}_{4}$-NPs intravenously (retroorbital sinus). Five minutes before use, the NPs were dispersed for $1 \mathrm{~min}$ with an ultrasonic homogenizer at $20 \mathrm{kHz}$ and $300 \mathrm{~W}$. It had been shown in pilot experiments that the values of the MRI signal in olfactory epithelium (OE) and OB reached their maximum in both intravenous and intranasal injections $12 \mathrm{~h}$ after the NP injection. To determine the patterns of $\mathrm{Mn}_{3} \mathrm{O}_{4}-\mathrm{NP}$ accumulation, MRI of the mouse brain was performed twice: $24 \mathrm{~h}$ before and $12 \mathrm{~h}$ after administration. Comparison of the obtained values of the MRI signal before and after the presentation of the NPs made it possible to assess the significance of manganese accumulation in brain divisions.

In order to investigate the role of olfactory neurons in capturing and transporting manganese nanoparticles, mice were treated with $10 \mu \mathrm{L}$ of the following compounds before intranasal/intravenous administration of nanoparticles into each nostril:

- chlorpromazine (C8138 SIGMA, Sigma-Aldrich) is a spe- 
cific inhibitor of clathrin-dependent endocytosis (Wang et al., 1993; Boucrot et al., 2015). The drug was administered at a dose of $0.4 \mathrm{mg} / \mathrm{kg}$;

- methyl- $\beta$-cyclodextrin (332615 SIGMA, Sigma-Aldrich) destroys lipid rafts (Brownell et al., 2011), participating in the capture of substances by endothelium cells. The drug was administered at a dose of $0.4 \mathrm{mg} / \mathrm{kg}$;

- zinc chloride (229997 SIGMA, Sigma-Aldrich), inducer of olfactory epithelial cell death (Burd, 1993). The drug was administered at a dose of $20 \mathrm{mg} / \mathrm{kg}$;

- colchicine (C9754 SIGMA, Sigma-Aldrich) inhibits tubulin polymerization, endocytosis and cellular transport (Castel, 1990). The drug was administered at a dose of $0.2 \mathrm{mg} / \mathrm{kg}$.

For each substance, eight animals were tested. Colchicine and chlorpromazine were injected $20 \mathrm{~min}$ and zinc chloride solution $24 \mathrm{~h}$ before the intranasal application of $\mathrm{Mn}_{3} \mathrm{O}_{4}-\mathrm{NPs}$ with respect to the onset of the effect.

MRI studies. The accumulation of paramagnetic nanoparticles in brain divisions of the mouse was investigated using MRI on the Ultra-High-Definition BioSpec 117/16 USR Tomograph (Bruker, Germany) - 11.7 T. MRI scans and the subsequent processing of the obtained images were carried out in accordance with previously developed protocols (Romashchenko et al., 2017).

Statistics. To compare the two means, we used the MannWhitney U test. Multiple mean comparisons were performed using the LSD test (Least Significant Difference). Data are expressed as mean $\pm \mathrm{SE}$.

\section{Results}

To analyze the patterns of $\mathrm{Mn}_{3} \mathrm{O}_{4}$-NPs distribution with two routes of their administration, we selected mouse brain regions demonstrating a significant increase in MRI signal amplitude $12 \mathrm{~h}$ after the administration in comparison to control
(Fig. 2,a). In both groups, injection of $\mathrm{Mn}_{3} \mathrm{O}_{4}$-NPs resulted in a statistically significant increase in manganese accumulation in $\mathrm{OB}$ and $\mathrm{OE}$ (see Fig. 2, b). In experiments with both intranasal and intravenous $\mathrm{Mn}_{3} \mathrm{O}_{4}$-NPs administration, the maximum signal level was recorded in $\mathrm{OB}$ (see Fig. 2). The level of MRI signal in OE and OB was higher when $\mathrm{Mn}_{3} \mathrm{O}_{4}$-NPs was injected into the nasal cavity than in the retroorbital sinus, and manganese accumulation in the dentate gyrus of the hippocampus (DG) was higher after intravenous administration of $\mathrm{Mn}_{3} \mathrm{O}_{4}$-NPs (see Fig. 2, $b$ ).

Thus, the propagation of $\mathrm{Mn}_{3} \mathrm{O}_{4}$-NPs after intranasal or intravenous injection was limited mainly by the structure of the olfactory system (see Fig. 2). This raises the question of the role of the olfactory epithelium in the penetration of nanoparticles into the brain from both the nasal cavity and the vascular bed. Data from the literature suggest that the mechanism of nanoparticle nose-to-brain transport is their endocytosis by olfactory neurons with subsequent axonal transport into the glomerular layer of $\mathrm{OB}$, where they cross the synaptic contact and migrate to the mitral cells. We hypothesized that $\mathrm{Mn}_{3} \mathrm{O}_{4}$-NPs accumulate in $\mathrm{OB}$ and areas of the olfactory tract through the uptake of NPs by olfactory neurons from blood. To test this hypothesis, we used an inhibitor of clathrin-dependent endocytosis (chlorpromazine), an inhibitor of axonal transport (colchicine), a substance that destroys lipid rafts involved in the uptake of substances by endothelial cells (methyl- $\beta$-cyclodextrin, (András et al., 2012)) and zinc chloride, an inducer of the death of olfactory epithelium cells. Both the inducer of OE cell death and the inhibitor of axonal transport almost completely prevented the accumulation of $\mathrm{Mn}_{3} \mathrm{O}_{4}$-NPs in OB during their preliminary intranasal application (Fig. 3). The inhibitor of clathrin-dependent endocytosis, being introduced into the nasal cavity, reduced the accumulation of $\mathrm{Mn}_{3} \mathrm{O}_{4}$-NPs in $\mathrm{OE}$ and $\mathrm{OB}$ only after their $a$

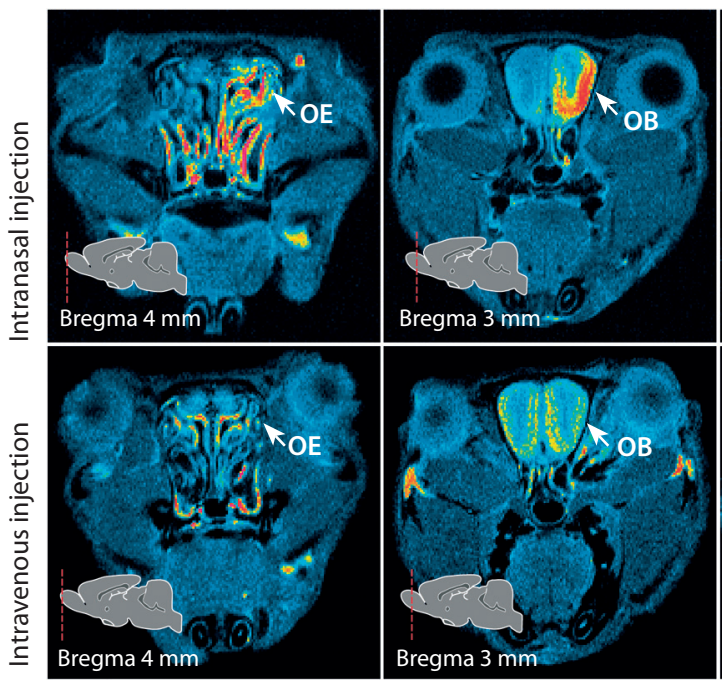

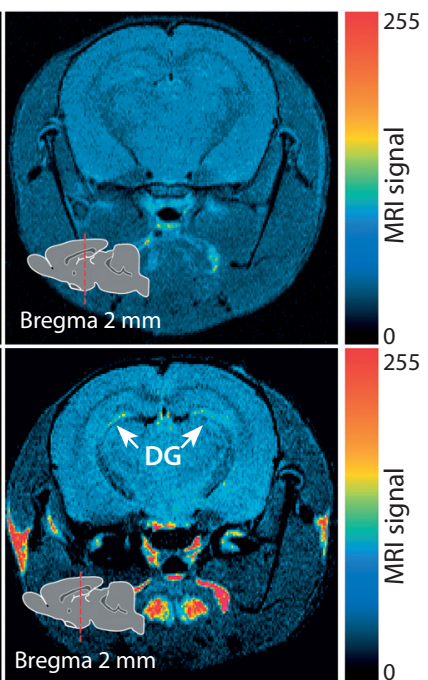

$b$

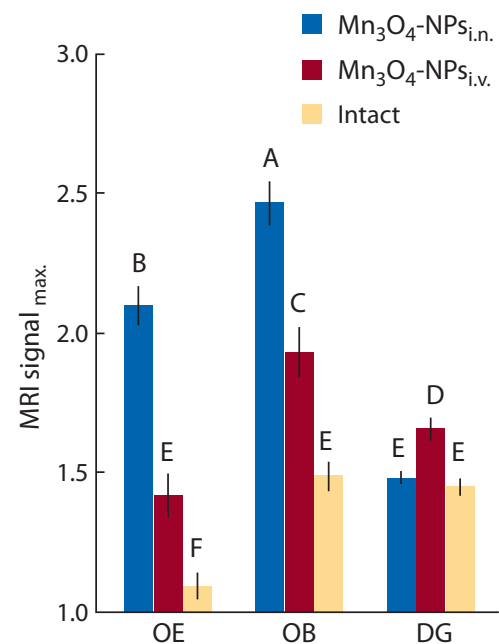

Fig. 2. Patterns of $\mathrm{Mn}_{3} \mathrm{O}_{4}-\mathrm{NP}$ accumulation in olfactory bulbs (OB), olfactory epithelium (OE) and dentate gyrus (DG) with their intranasal ( $a$, top panel) and intravenous ( $a$, bottom panel) administration.

White arrows indicate hyperintense sites corresponding to the accumulation of $\mathrm{Mn}_{3} \mathrm{O}_{4}$-NPs. The patterns of manganese particle accumulation on the MRI scan were visualized by pseudo staining; $b$ - quantitative assessment of changes in the level of MRI signal in OB, OE, and DG $12 \mathrm{~h}$ after intranasal (i.n.)/intravenous (i.v.) administration of $\mathrm{Mn}_{3} \mathrm{O}_{4}$-NPs. To assess the accumulation of nanoparticles in the region, the MRI signal normalized relative to the reference was used. Intact. averaged values of the MRI signal in $\mathrm{OB}, \mathrm{OE}$, and $\mathrm{DG}$ in animals before intranasal/intravenous injection of NPs. A-F - the significance of differences in mean values (LSD test, $p<0.05)$ 


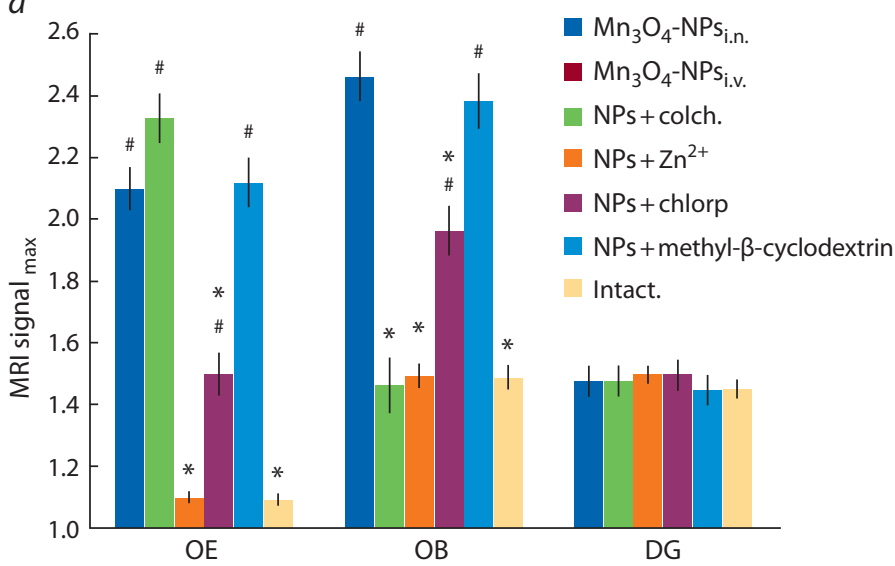

$b$

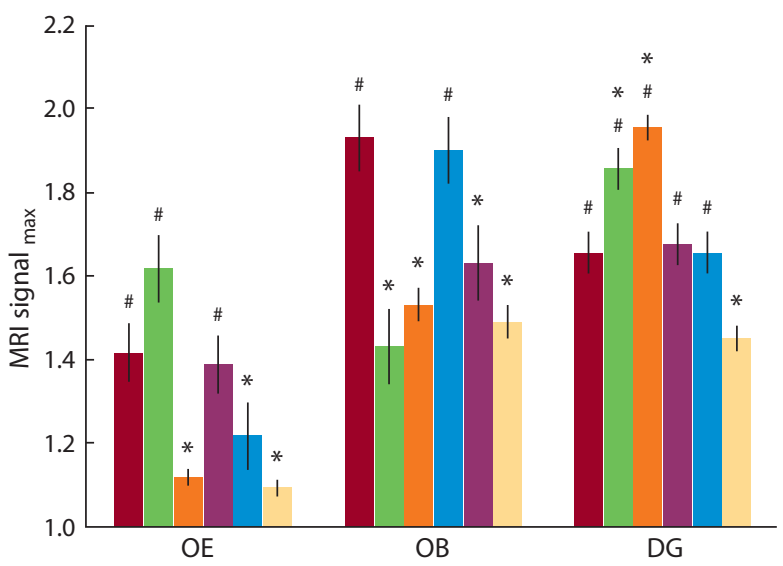

Fig. 3. Effect of intranasal application of inhibitors of endocytosis and axonal transport on the accumulation of $\mathrm{Mn}_{3} \mathrm{O}_{4}-\mathrm{NPs}$ in olfactory bulbs $(\mathrm{OB})$, olfactory epithelium (OE), and the dentate gyrus (DG) of a mouse $12 \mathrm{~h}$ after their introduction into the nasal cavity $(a)$ or the bloodstream (b).

To assess the accumulation of nanoparticles in the region, the MRI signal normalized relative to the reference was used. Intact. - averaged amplitudes of the MRI signal in $\mathrm{OB}, \mathrm{OE}$, and DG in animals before intranasal/intravenous injection of NPs; ${ }^{*}$ - significant differences compared with the control group, which was administered only NPs (Mann-Whitney $\mathrm{U}$ test, $p<0.05$ ); $\#$ - significant differences compared with intact animals, before the introduction of the NPs (MannWhitney $U$ test, $p<0.05)$; colch - colchicine; chlorp - chlorpromazine; $\mathrm{m} \beta \mathrm{cd}$ - methyl- $\beta$-cyclodextrin.

presentation in the nasal cavity. Intranasal administration of methyl- $\beta$-cyclodextrin significantly reduced the accumulation of $\mathrm{Mn}_{3} \mathrm{O}_{4}$-NPs in OE and OB only after their intravenous injection. None of the inhibitors applied to the nasal cavity had a significant effect on the level of MRI signal in the dentate gyrus (see Fig. 3). The results indicate a significant role of olfactory transport in the penetration and propagation of nanoparticles within the olfactory tract from both the surface of the nasal cavity and the bloodstream.

\section{Discussion}

In this work, we investigated the patterns of accumulation of $\mathrm{Mn}_{3} \mathrm{O}_{4}$-NPs in brain divisions of mice after their intravenous and intranasal presentation. The presence of manganese in brain tissue is apparent from the enhancement of the signal in T1 weighted MRI images, whose amplitude directly depends on manganese concentration (Lin, Koretsky, 1997). In particular, the microelement analysis of OB isolated from mice immediately after the MRI study showed a very close correlation between the intensity of the tomographic signal and the Mn content in the tissue (Romashchenko et al., 2017). All these observations provide grounds for considering the MRI signal amplitudes a semiquantitative indicator of the saturation of the brain tissue with manganese. The particles used in the work are practically insoluble in blood and slightly soluble at a $\mathrm{pH}$ corresponding to the acidic medium of lysosomes (Romashchenko et al., 2017). Therefore, the patterns of MRI contrast recorded in the first $12 \mathrm{~h}$ after $\mathrm{Mn}_{3} \mathrm{O}_{4}$-NPs administration are likely to reflect the accumulation of NPs but not manganese (II) ions, known to penetrate into the intracellular space (Lin, Koretsky, 1997). The $\mathrm{Mn}_{3} \mathrm{O}_{4}$-NPs used by us had a sufficiently large hydrodynamic radius $(\sim 130 \mathrm{~nm})$, limiting their ability to force BBB. Therefore, after intravenous administration of $\mathrm{Mn}_{3} \mathrm{O}_{4}$-NPs, we observed the localized rather than the distributed nature of T1-weigthed MRI signal, associated with the accumulation of particles, only in OE, OB, and DG. Similar accumulation patterns were observed after the intranasal ap- plication of $\mathrm{Mn}_{3} \mathrm{O}_{4}$-NPs. Based on the level of the MRI signal, the highest concentrations of particles after injection in vein or the nasal cavity were recorded in OB and OE. In both cases, the MRI signal amplitude in OB was significantly higher than in $\mathrm{OE}$, and this difference can be attributed to features of $\mathrm{OB}$ anatomy. Each globule in $\mathrm{OB}$ is innervated by several olfactory neurons (Dhuria et al., 2010), which can cause concentration of the intranasally administered contrast in OB. The congruence of the accumulation patterns obtained with two routes of NP administration convinced us that in both cases the olfactory transport plays an important role in the nose-to-brain transport of NPs, which is possibly due to the endocytosis of particles by nasal epithelial cells and their subsequent axonal transport (Mori et al., 1995; Dhuria et al., 2010; Munster et al., 2012; Hopkins et al., 2014; John et al., 2014).

It had been shown that the application of dissolved zinc salts $(5 \%)$ to the surface of OE led to the almost complete death of olfactory neurons and supporting cells during the day (Burd, 1993). In our experiments, a preliminary ( $24 \mathrm{~h}$ before) introduction of zinc chloride solution caused the almost complete abolition of the MRI signal increase in OB. Subsequent experiments with the provision of colchicine, inhibiting axonal transport (Ribak et al., 1978), confirmed the hypothesis of the key role of olfactory neurons in the accumulation of $\mathrm{Mn}_{3} \mathrm{O}_{4}$-NPs in OB in both routes of administration. Also, experiments with the introduction of chlorpromazine, a specific inhibitor of clathrin-dependent endocytosis (Wang et al., 1993), and methyl- $\beta$-cyclodextrin, an inhibitor of lipid rafts (András et al., 2012), demonstrated differences in the mechanisms of NP uptake from the nasal cavities and bloodstream.

The application of inhibitors did not affect the accumulation of $\mathrm{Mn}_{3} \mathrm{O}_{4}$-NPs in DG. A statistically significant increase in the MRI signal in this region after intravenous administration of $\mathrm{Mn}_{3} \mathrm{O}_{4}$-NPs can be associated with intense neurogenesis in DG requiring additional structural (membrane) and energy resources. As a result, the trapping of substances from the 
bloodstream, partly by endocytosis, may increase. In turn, this process may increase the intensity of nanoparticle uptake.

\section{Conclusion}

We demonstrate a significant contribution of axonal transport to the entry of nanoparticles into the brain, from both the nasal cavity and the vascular bed. This explains the accumulation of various submicron particles (neurotropic viruses, insoluble xenobiotics, etc.) unable to permeate through BBB in the brain. The results will add to the understanding of the pathogenesis of various neurodegenerative diseases, as well as to studies of side effects of drugs administered intravenously.

\section{References}

András I.E., Eum S.Y., Toborek M. Lipid rafts and functional caveolae regulate HIV-induced amyloid beta accumulation in brain endothelial cells. Biochem. Biophys. Res. Commun. 2012;421(2):177-183. DOI 10.1016/j.bbrc.2012.03.128.

Astic L., Saucier D., Coulon P., Lafay F., Flamand A. The CVS strain of rabies virus as transneuronal tracer in the olfactory system of mice. Brain Res. 1993;619(1):146-156. DOI 10.1016/0006-8993(93) 91606-S.

Boucrot E., Ferreira A.P., Almeida-Souza L., Debard S., Vallis Y., Howard G., Bertot L., Sauvonnet N., McMahon H.T. Endophilin marks and controls a clathrin-independent endocytic pathway. Nature. 2015;517(7535):460-465. DOI 10.1038/nature14067.

Brook R.D., Bard R.L., Burnett R.T., Shin H.H., Vette A., Croghan C., Phillips M., Rodes C., Thornburg J., Williams R. Differences in blood pressure and vascular responses associated with ambient fine particulate matter exposures measured at the personal versus community level. J. Occup. Environ. Med. 2010;68:224-230. DOI 10.1136/oem.2009.053991.

Brownell W.E., Jacob S., Hakizimana P., Ulfendahl M., Fridberger A. Membrane cholesterol modulates cochlear electromechanics. Pflügers Arch. 2011;461(6):677-686. DOI 10.1007/s00424011-0942-5.

Burd G.D. Morphological study of the effects of intranasal zinc sulfate irrigation on the mouse olfactory epithelium and olfactory bulb. Microsc. Res. Tech. 1993;24(3):195-213. DOI 10.1002/jemt. 1070240302.

Castel M.N., Malgouris C., Blanchard J.C., Laduron P.M. Retrograde axonal transport of neurotensin in the dopaminergic nigrostriatal pathway in the rat. Neuroscience. 1990;36(2):425-430. DOI 10.1016/ 0306-4522(90)90438-A.

Chen H., Kwong J.C., Copes R., Tu K., Villeneuve P.J., Van Donkelaar A., Hystad P., Martin R.V., Murray B.J., Wilton A.S. Living near major roads and the incidence of dementia, Parkinson's disease, and multiple sclerosis: a population-based cohort study. Lancet. 2017; 389(10070):718-726. DOI 10.1016/S01406736(16)32399-6.

Chen Z., Meng H., Xing G., Yuan H., Zhao F., Liu R., Chang X., Gao X., Wang T., Jia G., Ye C., Chai Z., Zhao Y. Age-related differences in pulmonary and cardiovascular responses to $\mathrm{SiO}_{2}$ nanoparticle inhalation: nanotoxicity has susceptible population. Environ. Sci. Technol. 2008;42(23):8985-8992. DOI 10.1021/es800975u.

Dhuria S.V., Hanson L.R., Frey W.H. Intranasal delivery to the central nervous system: mechanisms and experimental considerations. J. Pharm. Sci. 2010;99(4):1654-1673. DOI 10.1002/jps.21924.

Donaldson K., Brown D., Clouter A., Duffin R., MacNee W., Renwick L., Tran L., Stone V. The pulmonary toxicology of ultrafine particles. J. Aerosol Med. 2002;15(2):213-220. DOI 10.1089/ 089426802320282338.

Hopkins L.E., Patchin E.S., Chiu P.L., Brandenberger C., SmileyJewell S., Pinkerton K.E. Nose-to-brain transport of aerosolised quantum dots following acute exposure. Nanotoxicology. 2014 8(8):885-893. DOI 10.3109/17435390.2013.842267.

John J.A.S., Ekberg J.A., Dando S.J., Meedeniya A.C., Horton R.E., Batzloff M., Owen S.J., Holt S., Peak I.R., Mackay-Sim A. Burkholderia pseudomallei penetrates the brain via destruction of the olfactory and trigeminal nerves: implications for the pathogenesis of neurological melioidosis. MBio. 2014;5(2):e00025-14. DOI 10.1128/mBio.00025-14.

Kampfrath T., Maiseyeu A., Ying Z., Shah Z., Deiuliis J.A., Xu X., Kherada N., Brook R.D., Reddy K.M., Parthasarathy S., Chen L.C., Moffatt-Bruce S., Sun Q., Morawietz H., Rajagopalan S. Chronic fine particulate matter exposure induces systemic vascular dysfunction via NADPH oxidase and TLR4 pathways. Circ. Res. 2011; 108(6):716-726. DOI 10.1161/CIRCRESAHA.110.237560.

Kennedy P.G.E., Chaudhuri A. Herpes simplex encephalitis. J. Neurol. Neurosurg. Psychiatry. 2002;73:237-238. DOI 10.1136/jnnp.73. 3.237 .

Khlebtsov N., Dykman L. Biodistribution and toxicity of engineered gold nanoparticles: a review of in vitro and in vivo studies. Chem. Soc. Rev. 2011;40(3):1647-1671. DOI 10.1039/C0CS00018C.

Kreyling W.G. Discovery of unique and ENM-specific pathophysiologic pathways: Comparison of the translocation of inhaled iridium nanoparticles from nasal epithelium versus alveolar epithelium towards the brain of rats. Toxicol. Appl. Pharmocol. 2016;299:41-46. DOI 10.1016/j.taap.2016.02.004.

Lin Y.J., Koretsky A.P. Manganese ion enhances T1-weighted MRI during brain activation: An approach to direct imaging of brain function. Magn. Reson. Med. 1997;38(3):378-388. DOI 10.1002/ mrm.1910380305.

Mistry A., Glud S.Z., Kjems J., Randel J., Howard K.A., Stolnik S., Illum L. Effect of physicochemical properties on intranasal nanoparticle transit into murine olfactory epithelium. J. Drug Target. 2009; 17(7):543-552. DOI 10.1080/1061186090305547.

Mori I., Komatsu T., Takeuchi K., Nakakuki K., Sudo M., Kimura Y. Parainfluenza virus type 1 infects olfactory neurons and establishes long-term persistence in the nerve tissue. J. Gen. Virol. 1995;76(5): 1251-1254. DOI 10.1099/0022-1317-76-5-1251.

Mori I., Nishiyama Y., Yokochi T., Kimura Y. Virus-induced neuronal apoptosis as pathological and protective responses of the host. Rev. Med. Virol. 2004;14(4):209-216. DOI 10.1002/rmv.426.

Mori I., Nishiyama Y., Yokochi T., Kimura Y. Olfactory transmission of neurotropic viruses. J. Neurovirol. 2005;11(2):129-137. DOI 10.1080/13550280590922793.

Moshkin M.P., Petrovski D.V., Akulov A.E., Romashchenko A.V., Gerlinskaya L.A., Ganimedov V.L., Muchnaya M.I., Sadovsky A.S., Koptyug I.V., Savelov A.A., Troitsky S.Y. Nasal aerodynamics protects brain and lung from inhaled dust in subterranean diggers, Ellobius talpinus. Proc. R. Soc. B: Biol. Sci. 2014;281(1792):919. DOI 10.1098/rspb.2014.0919.

Munster V.J., Prescott J.B., Bushmaker T., Long D., Rosenke R., Thomas T., Scott D., Fischer E.R., Feldmann H., De Wit E. Rapid Nipah virus entry into the central nervous system of hamsters via the olfactory route. Sci. Rep. 2012;2:736. DOI 10.1038/ srep00736.

Ribak C.E., Vaughn J.E., Saito K. Immunocytochemical localization of glutamic acid decarboxylase in neuronal somata following colchicine inhibition of axonal transport. Brain Res. 1978;140(2):315-332. DOI 10.1016/0006-8993(78)90463-8.

Romashchenko A.V., Petrovskii D.V., Sharapova M.B., Moshkin Y.M., Kuper K.E., Morozova K.N., Kiseleva E.V., Moshkin M.P. Olfactory transport efficiency of the amorphous and crystalline manganese oxide nanoparticles. Vavilovskii Zhurnal Genetiki i Selektsii = Vavilov Journal of Genetics and Breeding. 2017;21(7):848-855. DOI 10.18699/VJ17.305. (in Russian)

Sauder C., Staeheli P. Rat model of Borna disease virus transmission: epidemiological implications. J. Virol. 2003;77(23):12886-12890. DOI 10.1128/JVI.77.23.12886-12890.2003. 
Tanaka H., Park C.H., Ninomiya A., Ozaki H., Takada A., Umemura T., Kida H. Neurotropism of the 1997 Hong Kong H5N1 influenza virus in mice. Vet. Microbiol. 2003;95(1):1-13. DOI 10.1016/S0378 1135(03)00132-9.

Tranfield E.M., Walker D.C. Understanding human illness and death following exposure to particulate matter air pollution. Environmental Health-Emerging Issues and Practice. IntechOpen, 2012. DOI $10.5772 / 30264$.
Wang L.H., Rothberg K.G., Anderson R.G. Mis-assembly of clathrin lattices on endosomes reveals a regulatory switch for coated pit formation. J. Cell Biol. 1993;123(5):1107-1117. DOI 10.1083/jcb.123. 5.1107.

Zanusso G., Ferrari S., Cardone F., Zampieri P., Gelati M., Fiorini M., Farinazzo A., Gardiman M., Cavallaro T., Bentivoglio M., Righetti P.G. Detection of pathologic prion protein in the olfactory epithelium in sporadic Creutzfeldt-Jakob disease. N. Engl. J. Med. 2003; 348(8):711-719. DOI 10.1056/NEJMoa022043.

ORCID ID

A.V. Romashchenko orcid.org/0000-0002-0674-0574

D.V. Petrovskii orcid.org/0000-0002-0623-0363

Acknowledgements. The study was supported by the Russian Science Foundation, project 17-74-10081. Use of the equipment of the shared access center was supported by the Russian Ministry of Education and Science, unique identifier of the project RFMEFI62117X0015.

Conflict of interest. The authors declare no conflict of interest.

Received March 19, 2019. Revised April 16, 2019. Accepted April 16, 2019. 